\title{
PERTANGGUNGJAWABAN PELAKU USAHA PELANGI KONVEKSI PADA BARANG YANG CACAT PRODUKSI*
}

\author{
Oleh:
}

\author{
Anak Agung Sagung Nadya Prabandari•• \\ Ida Bagus Putu Sutama*.. \\ Program Kekhususan Hukum Perdata Fakultas Hukum \\ Universitas Udayana
}

\begin{abstract}
ABSTRAK
Dalam era perubahan dengan kemajuan teknologi membuat para pebisnis mulai berinovasi dalam mengembangkan perekonomian mereka. Perkembangan usaha konveksi semakin melejit pesat seiring perkembangan jaman dan tawaran yang membludak. Salah satu usaha konveksi yang ada di Kota Denpasar yakni Pelangi Konveksi yang dimiliki oleh Sdr. Dewa Gede Dipa Keramas Sutamaya. Dalam menjalankan usaha terdapat hambatan atau kendala dalam proses produksi, salah satunya terjadi barang yang rusak atau cacat produksi. Tujuan penulisan ini untuk mengetahui pertanggungjawaban pelaku usaha Pelangi Konveksi pada barang yang cacat produksi serta mengetahui penyelesaian sengketa yang dilakukan Pelangi Konveksi. Penulis menggunakan Metode Yuridis Empiris. Kemudian, jika melihat pada Pasal 19 UUPK terdapat tanggung jawab Sdr.Dipa sebagai pelaku usaha dengan memberikan ganti rugi jika terjadi kerusakan. Sdr.Dipa melakukan penyelesaian menggunakan cara negosiasi yang menghasilkan kesepakatan perpanjangan waktu bagi pihak Pelangi Konveksi guna melakukan penggantian barang yang cacat produksi dengan yang baru.
\end{abstract}

\section{Kata Kunci : Pertanggungjawaban, Konveksi, Cacat Produksi}

In an era of change with technological advances, business people have begun to innovate in developing their economies. The development of the convection business has skyrocketed as the era and offer are booming. One of the convection businesses in

*Pertanggungjawaban Pelaku Usaha Pelangi Konveksi pada Barang yang Cacat Produksi merupakan makalah ilmiah di luar ringkasan skripsi.

•-Anak Agung Sagung Nadya Prabandari adalah Mahasiswa Fakultas Hukum Universitas Udayana, Korespondensi: nadya.praban@yahoo.com

..Ida Bagus Putu Sutama adalah Dosen Fakultas Hukum Universitas Udayana 
Denpasar is Pelangi Konveksi which is owned by Mr. Dewa Gede Dipa Keramas Sutamaya. The purpose of this paper is to find out the accountability of Pelangi Konveksi business actors on defective goods as well as to find out the dispute resolution conducted by Pelangi Konveksi. The author use the Empirical Juridical Method. There are several obstacles that require Mr. Dipa to outsmart the problems that arise. One of them is when there are problems with defective goods. Then, if you look at Article 19 of Customer Policy Mr. Dipa carry out its responsibilities as a business actor by providing compensation in the event of damage. Mr.Dipa made a settlement using negotiations which resulted in an extension of the agreement for Pelangi Konveksi to replace defective goods with new ones.

\section{Keywords: Accountability, Convection, Disability Production}

\section{PENDAHULUAN}

\section{$1.1 \quad$ Latar Belakang}

Tidak dapat dipungkiri lagi, seiring dengan perkembangan zaman dan kemajuan teknologi, banyak perubahan-perubahan yang signifikan terjadi dalam kehidupan masyarakat. Perubahan ini tentu berdampak juga ke dalam kehidupan masyarakat. Tak jarang perubahan tersebut membawa dampak negatif, namun tak sedikit pula membawa dampak positif. Perubahan pada bidang ekonomi, sosial, politik dan budaya tentu terjadi secara fleksibel. Pada era perubahan atau yang lebih dikenal dengan era globalisasi.

Dalam era perubahan dengan kemajuan teknologi membuat para pebisnis mulai berinovasi dalam mengembangkan perekonomian mereka. Karena banyaknya persaingan bisnis yang ada dalam masyarakat. Persaingan tersebut membuat para pebisnis membuat kegiatan usaha yang sasarannya anak muda dengan kebutuhan dasar seperti baju, celana, jaket, dan lain-lain. Dari inovasi dan konsep tersebut mulai terbesit pikiran untuk membuat Toko atau Distro yang menyediakan kebutuhan 
masyarakat dalam hal Fashion atau pakaian baik laki-laki maupun perempuan. Tidak puas sampai disana, biasanya pebisnis mulai mengembangkan usahanya namun dalam bidang yang sama yakni memproduksi nya sendiri baik itu baju, kemeja, celana, jaket, dan produksi-produksi inovatif lainnya yang kemudian dijual kembali di tokonya atau disebarkan ke toko-toko lainnya. Dalam melakukan kegiatan usaha tersebut tentu harus didasarkan pada prinsip keadilan, kebersamaan, efisiensi, serta menjaga keseimbangan kemajuan dan kesatuan ekonomi nasional. ${ }^{1}$

Memproduksi barang seperti baju, kemeja, celana, jaket, dan lain-lain merupakan usaha yang pelaku usahanya disebut dengan pelaku usaha konveksi. Konveksi adalah kegiatan usaha yang dimiliki oleh satu orang atau lebih yang memiliki jangkauan pasar yang luas, modern, dan sangat fleksibel atau luwes yang berkembang di dalam kehidupan masyarakat.

Perkembangan usaha konveksi semakin melejit pesat seiring perkembangan jaman dan tawaran yang membludak. Pada tahuntahun politik saat ini, di Bali khususnya Denpasar terdapat sebuah Industri Konveksi dengan nama Pelangi Konveksi yang dimiliki oleh Sdr. Dewa Gede Dipa Keramas Sutamaya. Pelangi Konveksi banyak mendapatkan tawaran untuk memproduksi kaos dan kemeja hingga ribuan. Tidak hanya tahun-tahun politik, saat acara pengerupukan (sebelum nyepi) yang digunakan untuk mengarak ogoh-ogoh, Pelangi Konveksi banjir tawaran untuk memproduksi baju kaos.

Dalam memproduksi baju kaos, kemeja, celana, jaket, dan lain-lain tentu Pelangi Konveksi yang dimiliki oleh Sdr. Dewa Gede Dipa Keramas Sutamaya tentu akan menemukan hambatan-

${ }^{1}$ Hermansyah, 2009, Pokok-Pokok Hukum Persaingan Usaha di Indonesia, Kencana Prenada Media Group, Jakarta, h. 66 
hambatan atau kendala-kendala dalam proses produksinya. Seperti terjadinya barang yang rusak atau cacat produksi, barang yang salah ukuran, barang yang selesai tidak tepat pada waktu, ataupun keadaan memaksa (Fource Majeure) lainnya. Dengan hambatan-hambatan tersebut, tentu Pelangi Konveksi harus bertanggungjawab atas barang-barang tersebut sebagaimana yang tercantum dalam UU No. 8 Tahun 1999 tentang Perlindungan Konsumen yang selanjutnya disebut UUPK.

\subsection{Rumusan Masalah}

Tulisan ini mengangkat dua permasalahan diantaranya sebagai berikut:

1. Bagaimana pertanggungjawaban pelaku usaha Pelangi Konveksi pada barang cacat produksi?

2. Bagaimana penyelesaian sengketa yang dilakukan Pelangi Konveksi terhadapat barang cacat produksi?

\subsection{Tujuan Penulisan}

Tujuan dari penulisan jurnal hukum ini adalah untuk mengetahui pertanggungjawaban pelaku usaha Pelangi Konveksi pada barang yang cacat produksi dan penyelesaian sengketa konsumen yang dilakukan Pelangi Konveksi terhadapat barang cacat produksi.

\section{ISI MAKALAH}

\subsection{Metode Penulisan}

Jenis penelitian yang digunakan dalam tulisan ini adalah jenis penelitian yuridis empiris. Menurut Prof. Dr. I Made Pasek Diantha, Metode penelitian yuridis empiris adalah penelitian yang dilakukan dengan menggunakan suatu prosedur atau proses 
dengan melihat secara nyata atau riil terkait bagaimana hukum itu bekerja di dalam masyarakat. ${ }^{2}$ Jenis pendekatan dalam penulisan ini yaitu pendekatan analisis dengan menganalisa konsep-konsep dalam hukum atau analytical approach. Dalam penulisan E-Journal ini, penulis melakukan wawancara terhadap pelaku usaha atau pemilik Pelangi Konveksi atas nama Dewa Gede Dipa Keramas Sutamaya.

\subsection{Hasil dan Pembahasan}

\subsubsection{Pertanggungjawaban pelaku usaha Pelangi Konveksi pada barang yang cacat produksi}

Sdr. Dewa Gede Dipa Keramas Sutamaya (Dipa) merupakan seorang pelaku usaha dimana pelaku usaha merupakan seseorang yang mampu menggerakan dan menjalankan suatu kegiatan usaha atau dengan kuasanya diberikan kepada orang lain dengan tujuan memperoleh keuntungan. ${ }^{3}$ Penjelasan UUPK memberikan arti bahwa pelaku usaha adalah suatu koorporasi, Badan Usaha Milik Negara, pedagang, koperasi, dll. ${ }^{4}$

Pertanggungjawaban atau responsibility adalah keharusan seseorang untuk melaksanakan secara layak apa yang telah diwajibkan kepadanya. ${ }^{5}$ Dalam hukum perlindungan konsumen prinsip tentang tanggung jawab sangat penting. Tanggung jawab pada dasarnya dipikul oleh si pelanggar hak konsumen. Secara umum terdapat 5 prinsip tanggung jawab dalam hukum, yaitu

2 Pasek Diantha, I Made, 2016, Metodologi Penelitian Hukum Normatif dalam Justifikasi Teori Hukum, Prenada Media, Jakarta, h. 29

${ }^{3}$ Hasyim, Farida, 2009, Hukum Dagang, Sinar Grafika, Jakarta, h. 128.

${ }^{4}$ Celina Tri Siwi Kristiyanti, 2011, Hukum Perlindungan Konsumen, Jakarta, Sinar Grafika. h. 41

5 I Gusti Ayu Apsari Hadi, 2017, "Pertanggungjawaban Pejabat Pemerintah Dalam Tindakan Diskresi Pasca Berlakunya Undang-Undang Nomor 30 Tahun 2014 Tentang Administrasi Pemerintah", Kertha Patrika, Vol. 39, No. 01, P. 33-46, URL https://ojs.unud.ac.id/index.php/kerthapatrika/article/view/32707. hlm. 41 
kesalahan (liability based on fault), praduga selalu bertanggung jawab (presumption of liability), praduga selalu tidak bertanggung jawab (presumption of nonliability), tanggung jawab mutlak (strict liability), pembatasan tanggung jawab (limitation of liability). ${ }^{6}$

Dalam perlindungan konsumen, digunakan tanggung jawab mutlak dimana merupakan prinsip tanggung jawab yang menetapkan kesalahan tidak sebagai faktor yang menentukan. Pertanggungjawaban ini berbeda dengan pertanggungjawaban hukum lainnya. ${ }^{7}$ Prinsip tanggung jawab mutlak digunakan untuk menjerat pelaku usaha yang memasarkan produk yang merugikan konsumennya. Product Liability merupakan istilah tanggung jawab produk. 8 Tanggung jawab terhadap produk yang dihasilkan atau dijual oleh pelaku usaha salah satunya yaitu tidak boleh terdapat cacat. Cacat bisa terjadi dalam konstruksi barang (constraction defect), desain (design), dan/atau pelabelan (labeling defect). ${ }^{9}$

Dalam Pasal 1365 KUHPer mengatakan bahwa setiap perbuatan melawan hukum yang menimbulkan kerugian pada orang lain maka wajib hukumnya untuk mengganti kerugian dimana merupakan salah satu bentuk tanggung jawab atas apa yang telah diperbuatnya sehingga menimbulkan kerugian. ${ }^{10}$ Suatu perbuatan dapat dikatakan melawan hukum jika bertentangan dengan kewajiban hukum pelaku si pelaku dan/atau hak subjektif orang lain.

${ }^{6}$ Shidarta, 2004, Hukum Perlindungan Konsumen Indonesia, Jakarta, PT. Gramedia Widiasarana Indonesia. hlm. 72.

7 Az. Nasution, 1995, Konsumen dan Hukum, Jakarta, Sinar Harapan. hlm. 24

8 Rusli, T, 2012, "Tanggung Jawab Produk dalam Hukum Perlindungan Konsumen". Pranata Hukum, Vol. $7, \quad$ No.1. URL: http://jurnal.ubl.ac.id/index.php/PH/article/view/172. hlm. 81

${ }_{9}^{\text {Op. cit, hlm. } 81 .}$

10 Rudyanti Dorotea Tobing, 2015, Hukum, Konsumen, dan Masyarakat, Yogyakarta, Laksbang Mediatama. hlm. 21 
Jika dihubungkan dengan UUPK, maka terdapat kewajiban pelaku usaha dan hak konsumen. Kewajiban pelaku usaha dalam Pasal 7 UUPK seperti itikad baik, memberikan informasi yang jelas mengenai kondisi barang, tidak diskriminatif dalam memperlakukan konsumen, menjamin mutu barang sesuai dengan standar mutu yang berlaku, memberikan kesempatan mencoba serta memberikan jaminan atau garansi atas barang yang dibuat, memberikan kompensasi atas kerugian akibat pemakaian barang serta apabila barang tidak sesuai dengan perjanjian. Kemudian Pasal 4 UUPK mengenai hak konsumen yaitu hak atas kenyamanan, keamanan, dan keselamatan, memilih barang dan/atau jasa serta mendapatkan barang dan/atau jasa tersebut sesuai dengan nilai tukar dan kondisi serta jaminan yang dijanjikan; hak atas informasi yang benar, jelas, dan jujur mengenai kondisi dan jaminan barang dan/atau jasa; hak untuk didengar pendapat dan keluhannya atas barang dan/atau jasa yang digunakan; hak untuk mendapatkan advokasi, perlindungan, dan upaya penyelesaian sengketa perlindungan konsumen secara patut; hak untuk mendapat pembinaan dan pendidikan konsumen; hak untuk diperlakukan atau dilayani secara benar dan jujur serta tidak diskriminatif; hak untuk mendapatkan kompensasi, ganti rugi dan/atau penggantian, apabila barang dan/atau jasa yang diterima tidak sesuai dengan perjanjian atau tidak sebagaimana mestinya; hak-hak yang diatur dalam ketentuan peraturan perundang-undangan lainnya.

Berdasarkan wawancara antara penulis dengan Sdr. Dipa selaku pemilik Pelangi Konveksi bahwasanya pernah mengalami permasalahan terkait barang dalam hal ini baju yang salah dalam penyablonan. Namun, hal tersebut diatasi oleh Sdr. Dipa dengan kembali menimpa gambar baru diatas gambar lama. Dengan 
demikian, barang yang telah disepakati dengan gambar yang semula tidak sesuai dengan yang diperoleh oleh konsumen sehingga menimbulkan kerugian. Melihat pernyataan tersebut, nyatanya Pelangi Konveksi yang dimiliki Sdr. Dipa tidak melakukan kewajiban sebagaimana mestinya yang tertera dalam Pasal 7 huruf e UUPK serta melanggar hak konsumen Pasal 4 ayat 2 UUPK sehingga perbuatan tersebut dapat dikategorikan sebagai perbuatan melawan hukum dalam Pasal 1365 KUHPer yang mewajibkan adanya ganti kerugian karena dalam perlindungan konsumen menganut tanggung jawab mutlak.

Pada dasarnya, jika melihat pada Pasal 19 UUPK Sdr. Dipa dapat melakukan tanggung jawabnya sebagai pelaku usaha dengan memberikan ganti rugi jika terjadi kerusakan atau kerugian yang ditimbulkan akibat barang yang dihasilkan pelaku usaha. Konsumen dalam meminta pertanggungjawaban kepada pelaku usaha didasarkan pada product liability. Ganti rugi yang dapat dilakukan Sdr. Dipa dalam tenggang waktu 7 (tujuh) hari setelah transaksi dapat berupa pengembalian uang atau penggantian barang yang sejenis atau setara nilainya.

\subsubsection{Penyelesaian Sengketa Yang Dilakukan Pelangi Konveksi Terhadapat Barang Cacat Produksi}

Di dalam melakukan pemenuhan kewajiban pelaku usaha dan hak konsumen tidak selalu berjalan sesuai yang diinginkan sehingga dimungkinkan terjadinya sengketa antara pelaku usaha dan konsumen. ${ }^{11}$ Pilihan dalam upaya penyelesaian sengketa konsumen dapat dilakukan melalui jalur penyelesaian di luar pengadilan (non litigasi) dan proses penyelesian di pengadilan

11 Yusuf Shofie, 2003, Penyelesaian Sengketa Konsumen, Menurut UUPK, Teori dan Praktek Penegakan Hukum, Bandung, PT. Citra Aditya Bakti, hlm. 8 
(litigasi), sebagaimana ditegaskan dalam ketentuan Pasal 45 ayat (1) dan (2) UUPK. ${ }^{12}$ Upaya penyelesaian di luar Pengadilan dapat berupa Negosiasi, Mediasi, Konsiliasi, dan Arbitrase.

Sdr. Dipa dalam menyelesaikan sengketa yang terjadi akibat barang cacat produksi menggunakan jalur penyelesaian di luar pengadilan (non litigasi) yaitu dengan cara negosiasi. Negosiasi sering disebut dengan istilah penyelesaian damai oleh para pihak. Negosiasi merupakan proses konsensus yang digunakan untuk memperoleh kesepatan antara para pihak tanpa adanya keterlibatan pihak ketiga. ${ }^{13}$ Negosiasi juga dapat dikatakan sebagai bentuk interaksi sosial saat pihak-pihak yang terlibat berusaha untuk saling menyelesaikan tujuan yang berbeda dan bertentangan. Para pihak dalam negosiasi disebut Negosiator yang memiliki kepentingan yang sama maupun berbeda.

Sdr. Dipa melakukan negosiasi dengan konsumen yang dirugikan karena kelalaian Sdr. Dipa dalam melakukan penyablonan sehingga menimbulkan barang cacat produksi. Hal ini menunjukkan adanya itikad baik dari pelaku usaha Pelangi Konveksi untuk melakukan tanggung jawabnya terhadap kerugian yang ditimbulkan. Karena kesalahan terjadi dalam proses produksi, Sdr. Dipa melakukan negosiasi dengan menemui konsumen kemudian memberikan penawaran ganti rugi dalam bentuk penggantian baju dengan yang baru kemudian dilakukan

12 Ronald Saija, 2016, "Penyalahgunaan Keadaan Oleh Negara Dalam Praktik Perjanjian Pada Kajian Hukum Privat", Kertha Patrika, Vol. 38, No. 03, URL:https://ojs.unud.ac.id/index.php/kerthapatrika/article/view/30080/1845 1. hlm. 184

13 Ni Komang Ayu Nira Relies Rianti, "Tanggung Jawab Pelaku Usaha Terhadap Konsumen Dalam Hal Terjadinya Hortweighting Ditinjau Dari Undang-Undang RI No 8 Tahun 1999 Tentang Perlindungan Konsumen” Jurnal Magister Hukum Udayana, Vol. 6, No. 4 : 521 - 537, URL: https://ojs.unud.ac.id/index.php/jmhu/article/view/37177/23057.hlm.532533 
penyablonan ulang namun memerlukan tambahan waktu kurang lebih seminggu dari waktu yang janjikan atau pengembalian uang muka (down payment) yang telah dibayarkan oleh konsumen kepada pihak konveksi. Setelah melewati proses negosiasi tersebut, timbul kesepakatan antara kedua belah pihak untuk diberikannya perpanjangan waktu kepada pihak Pelangi Konveksi guna melakukan penggantian baju dengan yang baru serta dilakukan penyablonan ulang.

\section{PENUTUP}

\subsection{Kesimpulan}

Berdasarkan pembahasan sebelumnya, dapat ditarik dua simpulan sebagai berikut.

1. Pelangi Konveksi yang dimiliki Sdr. Dipa tidak melakukan kewajiban sebagaimana mestinya yang tertera dalam Pasal 7 huruf e UUPK serta melanggar hak konsumen Pasal 4 ayat 2 UUPK sehingga perbuatan tersebut dapat dikategorikan sebagai perbuatan melawan hukum dalam Pasal 1365 KUHPer yang mewajibkan adanya ganti kerugian karena dalam perlindungan konsumen menganut tanggung jawab mutlak.

2. Sdr. Dipa dalam menyelesaikan sengketa yang terjadi akibat barang cacat produksi menggunakan jalur penyelesaian di luar pengadilan (non litigasi) yaitu dengan cara negosiasi yang menghasilakan kesepakatan diberikannya perpanjangan waktu kepada pihak Pelangi Konveksi guna melakukan penggantian baju dengan yang baru serta dilakukan penyablonan ulang 


\subsection{Saran}

1. Sebaiknya Sdr. Dipa selaku pemilik Pelangi Konveksi wajib memenuhi Pasal 7 huruf e serta Pasal 4 ayat 2 UUPK agar dikemudian hari tidak terjadi suatu permasalahanpermasalahan yang timbul akibat pelaku usaha tidak memenuhi kewajiban sebagaimana yang telah diatur tersebut.

2. Jika memiliki permasalahan antara pelaku usaha dengan konsumen, sebaiknya dilakukan upaya penyelesaian di luar pengadilan atau non litigasi. Upaya penyelesaian di luar pengadilan dalam hal ini yakni negosiasi untuk mencapai kesepakatan para pihak berupa pengembalian uang atau penggantian barang yang sejenis atau setara nilainya. 


\section{DAFTAR PUSTAKA}

\section{Literatur}

Az. Nasution, 1995, Konsumen dan Hukum, Jakarta, Sinar Harapan

Hasyim, Farida, 2009, Hukum Dagang, Sinar Grafika, Jakarta

Hermansyah, 2009, Pokok-Pokok Hukum Persaingan Usaha di Indonesia, Kencana Prenada Media Group, Jakarta

Pasek Diantha, I Made, 2016, Metodologi Penelitian Hukum Normatif dalam Justifikasi Teori Hukum, Prenada Media, Jakarta

Rudyanti Dorotea Tobing, 2015, Hukum, Konsumen, dan Masyarakat, Yogyakarta, Laksbang Mediatama

Shidarta, 2004, Hukum Perlindungan Konsumen Indonesia, Jakarta, PT. Gramedia Widiasarana Indonesia.

Tri Siwi Kristiyanti, Cellina, 2011, Hukum Perlindungan Konsumen, Jakarta, Sinar Grafika

Yusuf Shofie, 2003, Penyelesaian Sengketa Konsumen, Menurut UUPK, Teori dan Praktek Penegakan Hukum, Bandung, PT. Citra Aditya Bakti

\section{Peraturan Perundang-Undangan}

Undang-Undang Nomor 8 Tahun 1999 tentang Perlindungan Konsumen (Lembaran Negara Republik Indonesia Tahun 1999 Nomor 42 dan Tambahan Lembaran Negara Republik Indonesia Nomor 3821)

\section{Jurnal}

Rusli, T, 2012, “Tanggung Jawab Produk dalam Hukum Perlindungan Konsumen". Pranata Hukum, Vol. 7, No.1. URL: http://jurnal.ubl.ac.id/index.php/PH/article/view/1 72

I Gusti Ayu Apsari Hadi, 2017, “Pertanggungjawaban Pejabat Pemerintah Dalam Tindakan Diskresi Pasca Berlakunya Undang-Undang Nomor 30 Tahun 2014 Tentang 
Administrasi Pemerintah", Kertha Patrika, Vol. 39, No. 01, P. 33-46, URL

https://ojs.unud.ac.id/index.php/kerthapatrika/article/v iew/32707

Ronald Saija, 2016, "Penyalahgunaan Keadaan Oleh Negara Dalam Praktik Perjanjian Pada Kajian Hukum Privat", Kertha Patrika, Vol. 38, No. 03, URL:https://ojs.unud.ac.id/index.php/kerthapatrika/arti cle/view/30080/18451

Ni Komang Ayu Nira Relies Rianti, "Tanggung Jawab Pelaku Usaha Terhadap Konsumen Dalam Hal Terjadinya Hortweighting Ditinjau Dari Undang-Undang RI No 8 Tahun 1999 Tentang Perlindungan Konsumen" Jurnal Magister Hukum Udayana, Vol. 6, No. 4 : 521 - 537, URL: https://ojs.unud.ac.id/index.php/jmhu/article/view/371 $77 / 23057$. 